\title{
Okul Öncesi Dönem Çocuklarının Gelişimlerinin Desteklenmesi: Sosyal Sorumluluk Projelerinin Rolü ${ }^{1}$
}

\author{
Supporting the Development of Preschool Children: The Role of Social \\ Responsibility Projects
}

\author{
Burcu ÇABUK* \\ Ayşenur GÜNAY** \\ Esra ILHAN***
}

\begin{abstract}
$\ddot{O} Z$
Okul öncesindeki çocukların gelişimlerinin desteklenmesinde sosyal sorumluluk projelerinin rolünün belirlenmesi amacıyla geliștirilen araştırma kapsamında "Her Güne Bir Etkinlik" (2017-2018) ile "Mamak'ta Bilim Yolculuğu - Dil ve Kavram Gelişimi Atölyeleri” (2018-2019) projeleri gerçekleştirilmiş, çocuklar arasında firsat eşitliği sağlamak, farklı uygulamalarla eğitimlerine katkıda bulunmak, ögretmenlere farklı eğitsel bakış açılarını göstermek, öğretmen adaylarının teorik bilgiyi oyunlaştırarak uygulamalarını sağlamak ve velilere oyunla eğitimin önemini benimsetmek amaçlanmış̧tır. Uygulamalar, üniversite kampüsünde 32 lisans öğrencisiyle kavram oyuncakları, etkileşimli kitap okuma, Orff Schulwerk temelli müzik eğitimi, çocuk yogasl, yaratıcı drama kullanılarak ve bahçe oyunları oynanarak gerçekleştirilmiştir. Bu durum araştırmasında, Ankara-Mamak'taki 198 anasinıfi evreninde, basit seçkisiz örnekleme yöntemi kullanılarak 1503 çocuğa, 110 ögretmene, 196 veliye ulaşllmuştır. Nitel veriler, araştırmacılar tarafindan gelişstirilen, geçerlik-güvenirlik çalışmaları yapılan yarı-yapılandırllmış görüş̧e ve gözlem formlarıyla elde edilmiş, betimsel analizlerle çözümlenmiştir. Araştırmada, çocukların özellikle dil, sosyal-duygusal, bilişsel gelişimlerinde ilerleme gözlemlenmiş; öğretmenlerin farkll oyunlar ve oyuncakları gördükleri, uygulamalarl gözlemleyerek kendilerinin de benzer etkinlikler gerçekleştirdikleri belirlenmiştir. Öğretmen adayları da lisans öğrenimlerinde edindikleri bilgileri deneyimlemişlerdir. Velilerden ise çocuklarının gelişimleriyle ilgili olumlu görüşler alınmıştır.
\end{abstract}

\section{ANAHTAR KELIMELER}

Okul Öncesi Eğitim, Sosyo-Ekonomik Düzey, Fırsat Eşitliği, Çocuk Gelişimi, Sosyal Sorumluluk, Proje, Oyun

\begin{abstract}
The aim of this research was to determine the role of social responsibility projects in supporting the development of preschool children through "One Activity Per Day" (2017-2018) and "Science Journey at Mamak - Language and Concept Development Workshops" (2018-2019) Projects. The aim of the projects were to ensure equality of young children, to contribute to their education with different practices, to show different educational perspectives to teachers, to make the teacher candidates transfer the theoretical knowledge to play applications, to teach the importance of educational games to parents. Concept toys, interactive book reading, Orff Schulwerk-based music education, children's yoga, drama and garden games were performed on the university campus with 32 undergraduate students. In this case study, the population was determined as 198 kindergarten in Mamak, Ankara and for sampling 1503 children, 110 teachers and 196 parents were reached by using simple random sampling method. Qualitative data were obtained through semi-structured interview forms and observation forms developed by the researchers. Validity and reliability studies were conducted and analyzed by descriptive analysis. Progress has been observed in children's language, social-emotional and cognitive development. It was determined that the teachers saw different games and toys and observed various activities. Pre-service teachers had a chance to experience they learned during their undergraduate education. Positive opinions were received from the parents about the development of their children.
\end{abstract}

KEYWORDS

Preschool Education, Socio-Economic Level, Equal Opportunity, Child Development, Social Responsibility, Project, Play

\begin{tabular}{|c|c|c|}
\hline \multicolumn{2}{|r|}{$\begin{array}{c}\text { Makale Geliş Tarihi / Submission Date } \\
\text { 22.12.2019 }\end{array}$} & $\begin{array}{c}\text { Makale Kabul Tarihi / Date of Acceptance } \\
23.07 .2020\end{array}$ \\
\hline Attf & $\begin{array}{l}\text { Çabuk, B., Günay, A. ve İlhan, E. ( } 20 \\
\text { Sorumluluk Projelerinin Rolü. Selcuk }\end{array}$ & $\begin{array}{l}\text { m Çocuklarının Gelişimlerinin Desteklenmesi: Sosyal } \\
\text { nler Meslek Yüksekokulu Dergisi, } 23 \text { (2), 497-512. }\end{array}$ \\
\hline
\end{tabular}

\footnotetext{
${ }^{1}$ Bu araştırmanın bir kısmı, 25-27 Nisan 2019 tarihleri arasında İstanbul'da Maltepe Üniversitesi’nde düzenlenen 14. Ulusal Okul Öncesi Öğretmenliği Öğrenci Kongresi’nde sözlü bildiri olarak sunulmuştur.

* Dr. Öğretim Üyesi, Ankara Üniversitesi Eğitim Bilimleri Fakültesi Temel Eğitim Bölümü Okul Öncesi Eğitimi Anabilim Dalı Cebeci/Ankara, cabuk@education.ankara.edu.tr, ORCID: 0000-0003-1166-9773

** Öğretmen, ORCID: 0000-0002-7105-7499

*** Öğretmen, ORCID: 0000-0002-7540-9340
} 


\section{GİRIŞ}

Toplum ve birey karşılıklı olarak etkileşim içerisindedir. Toplumsal değerler bireyin bilişsel, sosyalduygusal gelişimini etkilerken, bireyin eylemleri ise toplumu destekler ve toplumun gelişerek yenilenmesine yardımcı olur. Bireyin toplum üzerinde bu yönde önemli bir etkisinin olması onun değerli olduğunu gösterir. Geçmişten günümüze bireyler doğumlarından itibaren toplum tarafından hem yaşları hem de toplumun onlardan beklentileri doğrultusunda değerli görülmektedir. Alanın önde gelen araştırmacılarından Kağıtçıbaşı (1981)'nın bir araştırmasından elde edilen sonuçlara göre çocuk; aile bağlarını güçlendirmesi, neşe ve motivasyon kaynağı olması, kişiliğin gelişmesine katkı sağlaması, yetişkin olduğunda ailesine maddi yardım yapması, ailenin ve toplumun devamını sağlaması gibi nedenlerden dolayı toplum tarafindan değerli görülmektedir. Birtakım beklentilerden dolayı değerli görülen bireyin bu beklentileri yerine getirebilmesi için fiziksel, sosyal-duygusal, bilişsel olarak yeterli düzeyde gelişim göstermesi gerekmektedir. Bireylerin gelişimleri açısından kritik dönemler arasında yer alan en önemli yaş aralığı 0-6 yaştır. Okul öncesi dönem olarak nitelendirilen bu yaş aralığındaki çocuklar okul öncesi eğitim alabilmektedir.

Günümüzde, okul öncesi eğitim zorunlu olmasa da geçmişe oranla okul öncesi eğitime verilen önem artmaktadır. Özellikle, MEB 2023 Eğitim Vizyonu'nda Erken Çocukluk Eğitim dahilinde 5 yaş zorunlu eğitim kapsamına alınması planlanmıştır (MEB, 2018). 0-6 yaş aralığı, kişiliğin oluşması ve gelişmesi, yaşamını sürdürebilmesi için gerekli olan temel bilgi ve becerilerin kazanılması gibi açılardan kritik bir öneme sahiptir. Gelişim açısından önemli olan okul öncesi dönemde verilen eğitimler çocuğun fiziksel, sosyal-duygusal, dil, bilişsel gelişimleri ile özbakım becerilerini destekleyen deneyimler elde etmelerini sağlamaktadır. Okul öncesi dönemde verilen nitelikli eğitim, çocuğun gelişimini ve akademik başarısını olumlu yönde etkilemektedir (Başaran, 2006).

Okul öncesi eğitimin temel amaçları çocukların beden, zihin ve duygu gelişimlerini ve iyi alışkanlıklar kazanmalarını sağlamak, onları ilkokula hazırlamak, şartları elverişsiz çevrelerden ve ailelerden gelen çocuklar için ortak bir yetiştirme ortamı yaratmak, Türkçeyi doğru ve güzel konuşmalarını sağlamaktır (MEB, 2013). $\mathrm{Bu}$ amaçlarla gelişimin desteklendiği eğitim ortamları, her çocuk için aynı şartları barındıramayabilir. Sosyoekonomik düzeyi düşük bölgelerde yaşayan ve okul öncesi eğitime devam eden çocuklar bu bakımdan dezavantajlı grup olarak sayılmaktadır. Yine bu konuda MEB 2023 Eğitim Vizyonu'nda Erken Çocukluk Eğitim kapsamında "Şartları elverişsiz hanelerdeki çocukların erken çocukluk eğitiminde araç-gereç ihtiyacı karşılanacaktır.", "Erken çocukluk eğitiminde yoksul hane halkına çocuk gelişimini destekleyici temel materyaller sağlanacaktır." ve "Şartları elverişsiz yerleşim birimlerindeki çocukların beslenme ihtiyaçları karşılanacaktır." hedefleri yer almaktadır (MEB, 2018). Dezavantajlı grup olarak nitelendirilen bu çocuklar ile diğer çocuklar arasında firsat eşitliği sağlamak amacıyla Milli Eğitim Bakanlığı'nın çalışmalarına ek olarak, sosyal sorumluluk projelerinin yürütülmesi de büyük önem taşımaktadır. Sosyal sorumluluk projeleri sayesinde dezavantajlı grupta bulunan okul öncesi dönem çocuklarının gelişimlerine katkı sağlanmaktadır.

Sosyal sorumluluk projeleri, özellikle yükseköğrenim kurumlarında öğrenim gören öğretmen adaylarını, çocukların bulundukları ortamlarda takım çalışmalarına katılma ve grup çalışmalarını yürütme, iletişim becerileri ile birlikte problem çözme becerilerini geliştirme, takıma uyum sağlamayı ya da grup içinde liderlik üstlenerek sorumluluk alma konularında desteklemektedir. Türkiye'de öğretmen yetiştiren kurumların müfredatlarına 2006 y1lı itibariyle zorunlu ders olarak getirilen "Topluma Hizmet Uygulamaları" dersi kapsamında öğretmen adayları, bir dönem boyunca toplumda sorun teşkil eden bir konu üzerinde çalışarak kendilerine düşen görevleri yerine getirmeyi hedeflemektedirler. Aynı yıl Ankara Üniversitesi Eğitim Bilimleri Fakültesi'nde konuyla ilgili olarak bir çalıştay düzenlenmiş ve eğitim fakültelerinin topluma hizmet amacıyla yerine getirebilecekleri işlevleri tartışılarak sonuç raporu hazırlanmıştır (Ankara Üniversitesi Eğitim Bilimleri Fakültesi, 2006).

Türkiye'deki üniversitelerdeki bu projelere paralel olarak, yurtdışındaki birçok yükseköğrenim kurumunda da sosyal hizmet programları adı altında yıllardır uygulamalar geç̧ekleştirilmekte ve bu programlarda yer almak, kurumlardan mezun olmanın kriterleri arasında görülmektedir. Dünyadaki en eski sosyal hizmet programları arasında görülen iki program, Amerika Birleşik Devletleri’nde bulunan Washington Üniversitesi'nde ve Chicago Üniversitesi'nde yer almaktadır. Bu iki üniversitenin programlarının 20. yüzyılın başından beri devam ettirildiği bilinmektedir. Sosyal sorumluluk projelerinin öğretim kurumlarında yer almalarının genel amacı, öğrenim görenlerin toplumun sorunlarına aktif katılım sağlayarak bu sorunlar konusunda bilinç kazanmalarını desteklemek olarak görülmektedir. Öğretmen yetiştiren programlardaki amaçları arasında ise öğretmen adaylarının (1) yaptıkları bu çalışmaları bir öğretim yöntemi olarak görmelerini sağlamak, (2) vatandaşlık sorumlulukları konusunda bilinçlenmelerini desteklemek, (3) güncel öğretim yöntemlerini edinmelerini sağlamak, (4) yeni öğretim tekniklerine adapte olmalarını desteklemek, 
(5) öğrencilerin ihtiyaçlarını belirleyerek öğretim yapmalarını sağlamak ve (6) meslek hayatlarına atıldıklarında da bu gibi sosyal sorumluluk projelerine katılmaları konusunda teşvik etmek yer almaktadır (Anderson, 1998).

Çocukların gelişimlerine en fazla etki eden unsur öncelikle ailedir. Okul öncesi eğitimde çocuğun gelişimine katkı sağlamak amacıyla aileler eğitim-öğretim sürecine aile katılımı çalışmaları ve etkinlikleri yoluyla dahil olmaktadırlar. Aileler ile işbirliği içerisinde yürütülerek gerçekleştirilen eğitim-öğretim sürecinde öğretmen, belirlediği amaçlara ulaşmada daha başarılı olmaktadırlar. Ailelerin okulda gerçekleştirilen eğitim-öğretim sürecini evde desteklemeleri adına yaptıkları çalışmalar sayesinde kalıcı bilgiler elde edilmektedir. Bu nedenle ailelerin de sosyal sorumluluk projelerine dahil edilmeleri önemlidir.

Sosyal sorumluluk projeleri, çocuklara olduğu kadar projenin uygulamalarını gerçekleştiren bireylere de katkı sağlamaktadır. Taş (2017)'ın araştırmasına göre sosyal sorumluluk projeleri sayesinde bireyler farkındalık kazanmakta, mutluluk/vicdani rahatlama hissetmekte, bilinçlenmekte, sosyal çevrede daha dikkatli/sorumlu davranmakta, tecrübelerini paylaşmakta, etrafındaki insanları teşvik etmekte, farklı hayatları tanımakta, empati becerisi kazanmakta ve önyargıları kırılmaktadır.

Sosyal sorumluluk projelerinin; katılımcılara ve uygulayıcılara katkı sağlayabilmesi ile katılımcıların projede uygulanan çalışmaları yakın çevredeki diğer insanlara aktarabilmesiyle insanların bilinçlenmelerine destek olabilmeleri amaciyla belirli bir plan çerçevesinde gerçekleştirilmesi gerekmektedir. $\mathrm{Bu}$ nedenle projeler, sosyal sorumluluğun boyutlarına uygun olarak planlanmalıdır. Carroll (1991)'ın yaptığı bir çalışmada sosyal sorumluluğun boyutları daha ayrıntılı olarak incelenmiş ve Carroll'ın "Sosyal Sorumluluk Piramidi" adını verdiği model ortaya konmuştur (Carroll, 1991; Akt. Taş, 2017). Bu piramide göre sosyal sorumluluğun alt boyutları aşağıdaki gibi sıralanmıştır:

\section{Şekil 1: Sosyal Sorumluluk Piramidi}

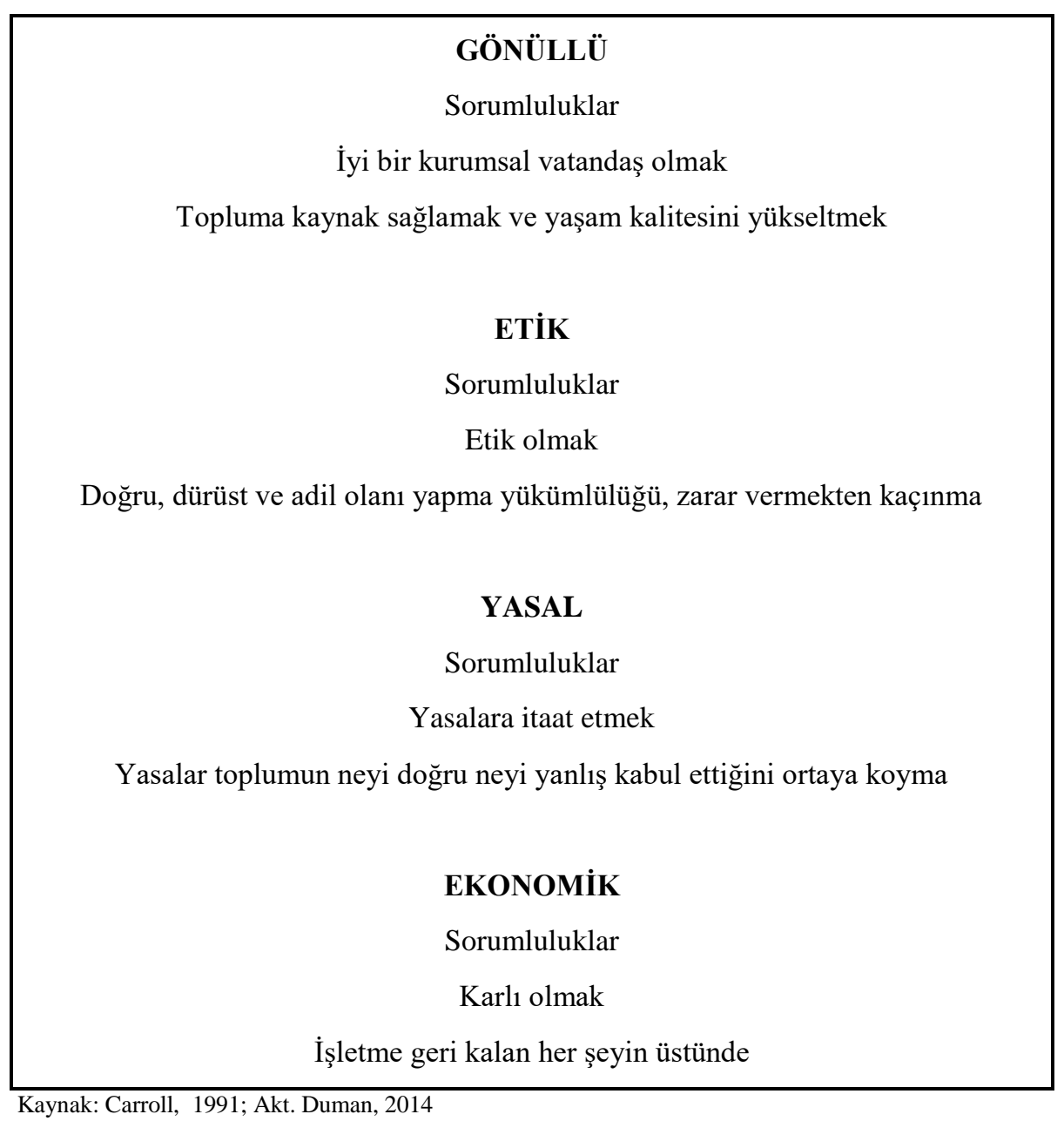

$\mathrm{Bu}$ araştırmada, sosyal sorumluluğun alt boyutlarından olan gönüllülük ilkesi göz önüne alınarak 20172018 eğitim-öğretim y1lında "Her Güne Bir Etkinlik" ve devamı niteliğinde 2018-2019 eğitim-öğretim yılında "Mamak'ta Bilim Yolculuğu-Dil ve Kavram Gelişimi Atölyeleri" isimli iki sosyal sorumluluk projesi 
geliştirilmiştir. Projeler oluşturulurken; dezavantajlı bölgelerden gelen çocuklara hizmet vermek amaciyla geliştirilen Head Start yaklaşımından (Temel, 2017) ve Okul Öncesi Eğitim Programı'ndaki okul öncesi eğitimin temel amaçlarından biri olan 'Elverişsiz çevrelerden gelen çocukları ortak yetiştirme ortamında desteklemek" amacından esinlenilmiştir (MEB, 2013). Proje fikirleri, Ankara Üniversitesi Eğitim Bilimleri Fakültesi’nde kısmi zamanlı olarak çalışan bir lisans öğrencisi ile gönüllü bir lisans öğrencisi tarafından (bu araştırmanın yazarlarından ikisidir) ortaya çıkmıştır. Fakültede görevli bir öğretim elemanına sunulan proje (bu araştırmanın diğer yazarıdır) daha sonra; dezavantajı bir bölge olan Ankara'nın Mamak İlçe Milli Eğitim Müdürlüğü yetkililerine, fakültede kısmi zamanlı olarak çalışan diğer lisans öğrencilerine, gönüllü olarak çalışmak isteyen diğer lisans öğrencilerine sunulmuş, geliştirilebilmesi için neler yapılabileceği hakkında tüm paydaşlardan görüşler alınmıştır.

Paydaşlardan alınan görüşler doğrultusunda projeyi, bilimsel temeller üzerine yerleştirmek amacıyla, literatür taraması yapılmıştır. Yurtdışında yapılan; örneğin; Garces, Thomas ve Currie (2002)'nin Head Start programının uzun süreli etkileri üzerine geliştirdikleri araştırmaları ve Webster-Stratton, Reid ve Hammond (2001)'ın Head Start programında veli ve öğretmen eğitimiyle ilgili araştırmaları incelenmiştir. Türkiye'de örneğin; Taner ve Başal (2002)'1n farklı sosyo-ekonomik düzeylerdeki okul öncesi eğitimi alan-almayan ögrencilere yönelik araştırmaları, Kandır ve Tümer (2013)'in farklı sosyo-ekonomik düzeylerdeki anasınıflarındaki beş-altı yaş çocuklarının erken öğrenme becerilerinin incelenmesi araştırmaları, Camgöz (2010)'ün etkileşimli akran oyunlarını 60-72 aylık düşük sosyo-ekonomik düzeydeki çocuklarla, ebeveynlerine ve öğretmenlerine katkılarıyla ilgili araştırması, Cevher (2015)'in Ankara' daki halk kütüphanesi çocuk bölümlerinin çocukların okuma alışkanlığındaki rolü ile ilgili araştırmalarından yararlanılmıştır. Alanyazın taraması sonrası, okul öncesi dönemdeki çocukların gelişimlerinin desteklenmesinde sosyal sorumluluk projelerinin rolünün belirlenmesi amacıyla geliştirilen araştırma kapsamında gerçekleştirilecek olan projelerde çocuklar arasında firsat eşitliği sağlamak, farklı uygulamalarla çocukların eğitimlerine katkıda bulunmak, yaparak-yaşayarak öğrenmelerini gerçekleştirmek, öğretmenlere farklı eğitsel bakış açılarını göstermek, öğretmen adaylarının teorik bilgiyi oyunlaştırarak uygulamalarını, velilerin oyunla eğitimin önemini benimsemelerini sağlamak amaçlanmış ve projelerin hitap edeceği okulların belirlenmesi yapılmıştır. Bu konuda Ankara ili Mamak İlçesi Milli Eğitim Müdürlügü’nde görevli AR-GE Birimi ile yapılan ortak çalışmalarda en çok ihtiyacın olduğu okullar tespit edilmiştir.

\section{Problem Durumu}

Çocuğun gelişiminde 0-6 yaş dönemi oldukça önemli bir dönemdir. Bu dönemde çocuk, hızlı bir gelişim süreci içindedir ve ilk eğitimini ailede alır. Anne-babanın öğrettikleri ve yakın çevreden alınan bilgiler, çocuğun yaşamını önemli şekilde etkilemektedir. Ailelerin sosyo-ekonomik düzeyleri (SED) çocuklarına verdikleri eğitim üzerinde ve buna bağlı olarak çocukların bütün gelişim alanları üzerinde önemli bir etkiye sahiptir.

Deniz, Türe, Uysal ve Akar (2015)'nın yaptıkları çalışmaya göre SED'in ailenin "gelir düzeyi”, "annebaba eğitim düzeyi", "sosyal etkinliğe katılma sıklı̆̆ı", "bir yıl içinde eve alınan okuma kitabı sayısı", "yaşanılan çevre" ile ilişkili olduğu sonucuna varılmıştır (Deniz, Türe, Uysal ve Akar, 2015: 7). Bradley ve Crowyn (2002)'in yaptıkları araştırmada ise, SED'in eğitim düzeyi, meslek durumu ve gelir düzeyi, bireylerin doğum öncesinde başlayan ve yetişkinlikte devam eden sağlık durumları, bilişsel-toplumsal-duygusal gelişimleriyle ilişkili olduğu sonucuna varılmıştır. Bu sonuçlar, alt SED’e sahip ailelerdeki çocukların bazı gelişimsel gerilikler gösterdiği, alt SED'deki yaşamsal koşullarına bağlı olarak akademik başarılarının düşük olmasının, bilişsel ve duyuşsal başarısızlıkları da beraberinde getirmesi ve sosyal çevrelerinde dışlanmaları gibi araştırma bulgularıyla desteklemişlerdir.

Okul öncesi dönemde, çocuğun, iyi bir eğitim yoluyla temellerini attığı becerilerini ileriki yaşantısında geliştirerek kullanabilmesi söz konusudur. $\mathrm{Bu}$, onu hem topluma kazandırır, hem de özgüveni yüksek ve başarılı bir birey haline getirir. Okul öncesi eğitimden yoksun olan veya yeterli düzeyde eğitim almamış olan çocukların bilişsel, duyuşsal, sosyal-duygusal gelişimleri tam olarak ilerleyemez ve desteklenmesi gereklidir. Dezavantajlı ortamlardan olan alt SED'de yaşamlarını sürdüren çocukların dil yetersizliği, uyum sorunları, bulunduğu ortamlarda kendini ifade etme becerilerinde yetersizlikler söz konusu olabilmektedir. Bu durumu çocukların lehine çevirmek ve çocuklara firsat eşitliği sağlamak için araştırma dahilinde birbirini takip eden iki ayrı proje yürütülmüştür. Projelerle, çocukların daha özgüvenli, akademik başarıları daha yüksek; ileriki yaşamlarında ise topluma ve yaşama tutunan bireyler haline gelmesi ve gelişim alanlarının desteklenmesi için çalışılmıştır. 


\section{Araştırmanın Amacı}

$\mathrm{Bu}$ araştırmanın amacı, okul öncesi dönemdeki çocukların gelişimlerinin desteklenmesinde sosyal sorumluluk projelerinin rolünü belirlemektir. Bu amaçla araştırma kapsamında "Her Güne Bir Etkinlik" ve "Mamak'ta Bilim Yolculuğu - Dil ve Kavram Gelişimi Atölyeleri” projeleri uygulanmıştır. Bu iki projenin ortak amaçları aşağıda sıralanmıştır:

a. Projelere katılan okul öncesi dönem çocuklarının eğitimlerine kavram oyuncakları, etkileşimli kitap okuma, Orff Schulwerk temelli müzik eğitimi [Carl Orff tarafından oluşturulan yöntemde oyun ve orff çalgıları önemli yer tutar. Müzik-dil-hareket yaklaşımın birleşme noktasıdır. Elementer müzik kavramını ortaya atmıştır (Kuşçu, 2010).], çocuk yogası, yaratıcı dramanın kullanıldığı ve bahçe oyunları gibi farklı oyun temelli uygulamalarla katkıda bulunmak, yaparak yaşayarak öğrenme felsefesini benimseyerek aktif katılımlarıyla öğrenmelerini sağlamak, çocukların özellikle sosyal-duygusal gelişim, dil gelişimi ve bilişsel gelişim alanlarını desteklemek,

b. Projelere katılan öğretmenlerle değişik ve güncel eğitsel bakış açılarını paylaşmak, çocukların tüm gelişim alanlarını desteklemelerine ve toplumda firsat eşitliği sağlamalarına katkıda bulunmak,

c. Projelerde görevli kısmi zamanlı çalışan ve gönüllü olan okul öncesi öğretmenliği lisans öğrencilerinin, lisans öğrenimlerinde teorik olarak edindikleri bilgileri farklı çocuk gruplarıyla gerçekleştirdikleri uygulamalarla pratik hale getirerek öğretmenlik deneyimlerinin zenginleştirmek,

d. Velilerin okul öncesi eğitim hakkında daha fazla bilgi sahibi olmaları, çocukların gelişsimlerini daha yakından takip etmeleri ve çocuklarının gelişimlerine oyun temelli uygulamalar ile katkıda bulunabilmelerini sağlamak amaçlanmıştır.

Araştırmanın Önemi

$\mathrm{Bu}$ araştırma kapsamında birbirleri ardına geliştirilen iki proje, sosyo-ekonomik düzeyi düşük, elverişsiz ortamlardan gelen ve kendilerini ifade etmede yetersizlikleri olan çocuklar için fırsat eşitliği sağlaması, çocuğa yeni öğrenme ortamları sunması, çocuğun gelişimini her yönden desteklemesi, çocuğun, ailenin, öğretmenlerin yeni materyal ve oyuncakları deneyimlemesi açısından önemlidir. Konuyla ilgili araştırmalar alanyazın taramasıyla incelenmiştir:

Dinçer, Ergül, Şen ve Çabuk (2011)'un yaptıkları araştırmada topluma hizmet uygulamaları kapsamında "Haydi Kavram Oyuncaklarıyla Oynayalım” projesinde okul öncesi eğitim alamayan çocuklar ile uygulamalar gerçekleştirilmiştir. Kavram oyuncaklarıyla gerçekleştirilen uygulamaların, çocukların kavram bilgilerinin desteklenmesi, ailelerin okul öncesi eğitim hakkında farkındalık kazanması ve projeye dahil olarak kavram oyuncaklarını geliştiren okul öncesi eğitimi öğretmenliği anabilim dalı lisans öğrencilerinin topluma duyarlı birey olmaları ve toplumsal sorunların çözümünde önderlik etmeleri gibi nedenlerden dolayı önemli olduğu belirtilmiştir (Dinçer, Ergül, Şen ve Çabuk, 2011).

Haktanır, Akgün, Karaman ve Duman (2012)'ın yaptıkları araştırmada da benzer biçimde topluma hizmet uygulamaları kapsamında yürütülen "Mobil Anaokulu Projesi" ile yoksulluk nedeniyle eğitim haklarından yararlanamayan çocuklara ulaşmak amaçlanmıştır. Bu projede, çocukların bilişsel, dil, sosyal-duygusal ve psiko-motor gelişim alanları ile özbakım becerilerini desteklemek ve lisans öğrencilerinin eğitim programını farklı koşullarda da uygulamayı denemelerine firsat verilmesi ve sürecin sonunda yapılan değerlendirme ile de öğretmen adaylarının çocuklardaki gelişimi gözlemleyebilmeleri bakımından önemli olduğu belirtilmiştir (Haktanır, Akgün, Karaman ve Duman, 2012).

Benzer bir başka sosyal sorumluluk projesinde, 20 okul öncesi öğretmeni adayı, lösemiden kurtulan çocuklar, kadın sığınma evlerinde yaşayan ve aile içi şiddete maruz kalan çocuklar, devlet kurumlarına bırakılan çocuklar ile bir sebeple okul öncesi eğitime devam edemeyen çocuklar ile çalışmışlardır. Toplam 50 çocukla çeşitli etkinlikler gerçekleştirmişler ve çocukların özellikle temel kavram gelişimlerine ve sosyal becerilerinin gelişimlerine destek olmaya çalışmışlardır (Akgün, Karaman ve Dinçer, 2011).

Yapılan literatür taramasında MEB'in belirlemiş olduğu okul öncesi eğitimin temel amaçlarına ulaşabilmek için aile ve öğretmen arasında ortak bir eğitim anlayışı oluşturmanın önemli olduğu vurgusuna rastlanmıştır. $\mathrm{Bu}$ ortak eğitim anlayışı sayesinde çocukların gelişimlerinde ilerlemeler kaydedilebilir. Bu nedenle sosyal sorumluluk projelerine ailelerin ve öğretmenlerin dahil edilmesi önem teşkil etmektedir. Okul öncesi eğitimin amaçlarından biri, şartları elverişsiz çevrelerden ve ailelerden gelen çocuklar için ortak bir yetiştirme ortamı oluşturmaktır. Bu amaca ulaşabilmek için sosyal sorumluluk projelerinin faydalı olabileceği hipotezinden yola çıkılarak, literatürde rastlanan az sayıdaki çalışmalarda konu incelenmiş ve okul öncesi dönemdeki çocukların gelişimlerinin desteklenmesinde öğretmen adaylarının hem öğretmenleri, hem de velileri işin içine dahil edebilecekleri sosyal sorumluluk projelerinin rolünü belirlemek amacıyla konu araştırmaya değer bulunmuş ve bu araştırma geliştirilmiştir. 


\section{YÖNTEM}

\subsection{Araştırma Modeli}

Okul öncesi dönem çocuklarının gelişimlerinin desteklenmesi amacıyla yapılan bu araştırma, nitel araştırma yöntemlerinden durum çalışması ile gerçekleştirilmiştir. Nitel araştırma, gözlem, görüşme ve doküman analizi gibi nitel veri toplama yöntemlerinin kullanıldığı, görüşlerin ve olayların doğal ortamda gerçekçi ve bütüncül bir biçimde ortaya konulmasına yönelik nitel bir sürecin izlendiği araştırmadır. Durum çalışması, bilimsel sorulara cevap aramada kullanılan bir yaklaşım olarak görülmektedir. Durum çalışması, bir olayı meydana getiren ayrıntıları tanımlamak ve görmek, bir olaya ilişkin olası açıklamaları geliştirmek, bir olayı değerlendirmek amacıyla kullanılır (Büyüköztürk, Çakmak, Akgün, Karadeniz ve Demirel, 2017). Bu araştırmada, iki ayrı projede dezavantajlı olduğu tespit edilen okul öncesi dönem çocuklarının öğretmenleriyle ve gönüllü velilerle üniversite kampüsüne gelerek öğretmen adayları eşliğinde çeşitli etkinlikler (tanışma oyunları, yaratıcı drama, çocuk yogası, Orff Schulwerk temelli müzik eğitimi, etkileşimli kitap okuma, kavram oyuncakları ve bahçe oyunları) ile bilişsel, sosyal-duygusal, psiko-motor ve dil becerilerinin desteklenmesi sağlanmaya çalışılmıştır. Her çocuğun, kampüse her gelişinde tüm etkinlik türlerinden yararlanması amaçlanarak ilk yıl "Her Güne Bir Etkinlik Projesi"nde 6-8 kere, ikinci yıl "Mamakta Bilim Yolculuğu - Dil ve Kavram Atölyeleri Projesi”nde, daha yoğun talep olması nedeniyle, 3-4 kere olacak şekilde eğitimlere katılmıştır. Çocukların ilgi ve dikkat sürelerine bağlı olarak her bir etkinlik 30-60 dakika arasında sürmüştür.

\section{2. Örneklem Grubu}

Araştırmada Ankara ilinin Mamak ilçesinde yer alan 198 anasınıfi evren olarak belirlenmiş (TÜİK, 2017), amaçlı örnekleme yöntemlerinden tipik durum örnekleme kullanılmıştır. Tipik durum örnekleme, örneklemin araştırma problemi ile ilgili olarak evrende yer alan çok sayıdaki durumdan tipik olan biriyle oluşturulmasıdır (Büyüköztürk, Çakmak, Akgün, Karadeniz ve Demirel, 2017). Örneklem kapsamında iki yıl süreyle toplamda ulaşılabilen sınıf sayısı 110 olarak tespit edilmiştir. Ulaşılan kişi sayıları ise aşağıda açıklanmaktadır:

Araştırma kapsamında; 2017-2018 eğitim-öğretim yılında geliştirilen "Her Güne Bir Etkinlik" projesi gerçekleştirilen ilk projedir. Bu projede Mamak ilçesinde yer alan dezavantajlı bölgelerden gelen 340 okul öncesi dönem çocuğuna, 22 Milli Eğitim Bakanlığı'na bağlı kurumlarda görev yapan okul öncesi öğretmenine, 44 gönüllü veliye ve 8 okul öncesi öğretmenliği lisans öğrencisine ulaşılmıştır. İlk projenin devamı niteliğinde olan ve 2018-2019 eğitim-öğretim yılında geliştirilen “Mamak'ta Bilim Yolculuğu-Dil ve Kavram Gelişim Atölyeleri” projesinde ise önceki proje daha da geliştirilip duyurulduğundan talep artmış ve yine Mamak ilçesinde yer alan dezavantajlı bölgeden gelen 1163 okul öncesi dönem çocuğuna, 88 görevli okul öncesi öğretmenine, 152 gönüllü veliye, 12 tecrübeli ve 12 tecrübesiz okul öncesi öğretmenliği lisans öğrencisine ulaşılmış ve bu lisans öğrencileriyle etkinlikler yürütülmüş̧ür. Tecrübeli lisans öğrencilerinin tecrübesiz lisans öğrencilerine akran eğitimi vermesi söz konusu olmuş ve lisans öğrencilerinin de deneyim kazanmaları pekiştirilmiştir. Böylece, iki yılda, toplamda 1503 okul öncesi dönem çocuğuna, 110 Milli Eğitim Bakanlığı'na bağlı kurumlarda görev yapan okul öncesi öğretmenine, 196 gönüllü veliye ve 32 okul öncesi öğretmenliği lisans öğrencisine ulaşılmıştır.

Çalışma grubundaki Milli Eğitim Bakanlığı'na bağlı kurumlarda görev yapan okul öncesi öğretmenlerinin hepsi kadındır. Okul öncesi öğretmenliği lisans öğrencileri, kısmi zamanlı olarak çalışan ve gönüllü olan 2., 3. ve 4. sınıf öğrencilerinden oluşmaktadır. Veliler, araştırmaya katılan çocukların velilerinden oluşmaktadır. Çocukların tamamı 60-72 ay arasında olan, anasınıfı öğrenimi gören, Mamak’taki sosyo-ekonomik düzeyi düşük, elverişsiz ortamlardan gelen ve dil yetersizlikleri olan çocuklardan oluşmaktadır.

\subsection{Veri Toplama Araçları}

Araştırmada veri toplama aracı olarak araştırmacılar tarafından geliştirilen yarı yapılandırılmış görüşme formları ve gözlem formları kullanılmıştır.

Yarı yapılandırılmış görüşme formu, görüşme sırasında önemli olan sorular veya konular listesini kapsar. "Görüşme formları, benzer konulara yönelmek yoluyla değişik insanlardan aynı tür bilgilerin alınması amacıyla hazırlanır." (Patton, 1987). Araştırmacı formda önceden hazırladığı konulara sadık kalıp, hem önceden hazırlanmış soruları sorma, hem de bu sorular konusunda daha ayrıntılı bilgi alma amacıyla ek sorular sorma özgürlüğüne sahiptir. Hazırladığı soruların sıralamasına bağlı kalma zorunluluğu yoktur. Görüşme formu, araştırmanın problemiyle alakalı tüm konuların ve soruların kapsanmasının güvence altına almak için geliştirilmiş bir yöntemdir. Araştırmacı, görüşmede soruların yapısını ve sırasını değiştirebilir, istediği konularda ayrıntıya gidebilir veya sohbet tarzı bir yöntem benimseyebilir (Yıldırım ve Şimşek, 2004). 
Okul öncesi dönem çocuklarının gelişimlerinin desteklenmesi amacıyla yapılan bu araştırmada araştırmacılar tarafından geçerlik ve güvenirlik çalışmaları Merriam (2013)'ın öngördüğü biçimde yapılarak;

- Öğretmen Görüşme Formu

- Çocuklara Yönelik Odak Grup Görüşmesi Formu

- Aday Öğretmen Görüşme Formu

- Veli Görüşme Formu

olmak üzere öğretmenler, çocuklar, aday öğretmenler ve veliler için toplamda dört görüşme formu geliştirilmiştir. Görüşme formlarının hazırlanmasında öncelikle araştırmanın amacı göz önünde bulundurulmuş ve konu hakkında literatür taraması yapılmıştır. İlgili literatür araştırması sonucunda bu çalışma kapsamında yer alabilecek soru havuzu oluşturulmuştur. Ardından oluşturulan bu soru havuzundan, nitel çalışmada yer alabilecek soru sayısı göz önünde bulundurularak Yarı Yapılandırılmış Görüşme Formları'nın soruları oluşturulmuştur. Yarı Yapılandırılmış Görüşme Formları, araştırmanın amacı, nitel çalışmaya uygunluğu açısından değerlendirilmek üzere geçerlik ve güvenirliği için üniversitede öğretim üyesi olan Ölçme ve Değerlendirme uzmanı, Dil uzmanı ve Okul öncesi eğitimi alanında uzman üç farklı uzmanın görüşüne sunulmuştur. Uzmanların değerlendirmeleri sonucunda sunulan görüşler dikkate alınarak yarı yapılandırılmış görüşme formlarına son şekilleri verilmiştir. "Öğretmen Görüşme Formu" kullanılarak öğretmenlerin; "Çocuklara Yönelik Odak Grup Görüşmesi Formu” kullanılarak çocukların, "Aday Öğretmen Görüşme Formu" kullanılarak öğretmen adaylarının ve "Veli Görüşme Formu" kullanılarak velilerin; yarıyapılandırılmış görüşmeler yoluyla eğitimle ilgili deneyimlerine yönelik görüşleri tespit edilmeye çalışılmıştır.

Araştırmada araştırmacılar tarafından geçerlik ve güvenirlik çalışmaları yapılarak "Öğretmen Adayları Gözlem Formu" da oluşturulmuştur. Literatür taraması yapılarak oluşturulan gözlem formunun geçerlik ve güvenirliği için üniversitede öğretim üyesi olan Ölçme ve Değerlendirme uzmanı, Dil uzmanı ve Okul öncesi eğitimi alanında uzman üç farklı uzmanın görüşüne sunulmuştur. Uzmanların değerlendirmeleri sonucunda sunulan görüşler dikkate alınarak "Öğretmen Adayları Gözlem Formu”na son şekli verilmiştir.

\subsection{Verilerin Toplanması ve Analizi}

$\mathrm{Bu}$ araştırmada kullanılan iki nitel araştırma yönteminde biri olan görüşme; nitel araştırma yönteminde en sık kullanılan veri toplama aracıdır. Görüşmenin etkili bir veri toplama aracı olarak kullanılabilmesi için bu yöntemin temel özelliklerini iyi anlamak, nitel verilere ulaşmayı kolaylaştıracak bir görüşme formu hazırlamada ve görüşmeyi gerçekleştirme sürecinde dikkate alınması önerilen ilkeleri özümseyerek işe koşmak gerekmektedir (Yıldırım ve Şimşek, 2004).

Görüşmenin temel amacı araştırmaya yönelik bilgiler toplamaktır. Araştırmacı, görüşme yaptığı kişinin aklında bulunanları öğrenmek ister. "Biz görüşmeyi doğrudan gözlem yapamadığımız durumlar için kullanırız. Duyguları, düşünceleri ve niyetleri gözlemleyemeyiz. Gözlemcinin içine giremediği durumları da gözlemleyemeyiz. İnsanların dünyayı nasıl organize ettiklerini ve dünyaya yükledikleri anlamları da gözlemleyemeyiz. Bütün bunları katılımcılara sorular sorarak öğrenebiliriz. O halde görüşmenin amac1 görüşme yapılan katılımcının bakış açısını öğrenmektir”' (Patton, 2002; Merriam, 2013).

Araştırma kapsamında geliştirilen yarı yapılandırılmış görüşme formları yüz yüze uygulanmış olup, uygulama süreci yaklaşık 20-25 dakika sürmüştür. Görüşme sürecinde veriler yazılarak ve ses kayıt cihazıyla kayıt altına alınmıştır. Görüşmelerin hepsi randevu alınarak gerçekleşmiştir. Görüşmeler sırasında güvenilirlik için araştırmaya katılan her gruba sorular aynı sırada yönlendirilmiştir.

Araştırma kapsamında kullanılan ikinci teknik olan gözlem tekniği ise bir ortamda ya da kurumda oluşan davranış1 ayrıntılı olarak tanımlamak amacıyla kullanılan bir yöntemdir. Araştırmacı, ortamda oluşan bir davranışa ilişkin ayrıntılı, kapsamlı ve zamana yayılmış veriler elde etmek istiyorsa, gözlem yöntemini kullanabilir (Bailey, 1982; Akt. Şimşek ve Yıldırım, 2004).

Karasar'a göre gözlemler için, gözlemlediği konuyla ilgili iyi eğitim almış ve objektif gözlemler yapabilecek, en az iki gözlemcinin kullanılması faydalı olduğundan dolayı her uygulamada araştırmacılardan en az ikisi gözlem yapmıştır (Karasar, 2005).

Çocukların etkinliklerde oyun ortamlarında gözlendiği bu araştırmada veriler, uygulama yapan okul öncesi öğretmenliği lisans öğrencileri tarafından araştırmacı gözlemci olarak hem etkinlikler ve oyunlar sırasında hem de etkinlikler ve oyunlardan hemen sonra kaydedilmiştir. Bu kayıtlar, etkinlik ve oyun sırasında video kayıtlarıyla yapılmıştır. Etkinlik ve oyunlardan sonra ise videolar izlenip kayıtlar tutularak "Öğretmen Adayları Gözlem Formu"na aktarılmıştır.

Okul öncesi dönem çocuklarının desteklenmesi amacıyla yapılan bu araştırmada verilerin değerlendirilmesinde betimsel analiz yöntemi kullanılmıştır. Çocuk yogası, yaratıcı drama, Orff Schulwerk 
temelli müzik eğitimi ve bahçe oyunları, geleneksel oyunlarla gerçekleştirilen etkinlikler boyunca yapılan öğretmen adayı gözlemleri, veli görüşleri, öğretmenlerin etkinliklere ilişkin görüşleri, çocuklarla yapılan görüşmeler ve ögretmen adayı görüşmeleri kayıt altına alınarak ileriye dönük etkinlikler, çalışmalar için iyileştirmeler yapılmıştır. Yapılan etkinlikler sonrasında önce çocukların süreç içerisindeki duygu ve düşünceleri, sonrasında ise videolar incelenerek etkinliklerin planlanmasında gelişimlerini destekleyici unsurlar dikkate alınarak işlenmiştir. Velilerin kayıt altına alınan görüş ve önerileri yazıya dökülmüştür. Uygulamalar boyunca görev alan lisans öğrencileri ile aylık toplantılar yapılarak yeni, yaratıcı ve öğretici etkinlikler planlanmıştır. Daha yapıcı düzenlemeler yapılmıştır. Süreç boyunca "Öğretmen Adayları Gözlem Formu" kullanarak zaman içerisinde yapılan etkinliklerin içeriği daha etkin ve kullanışlı olmak üzere geliş̧irilmiştir.

Betimsel analizde veriler, görüşülenden elde edildiği şekilde değiştirilmeden alıntılar şeklinde aktarılır. Bu analizde farklı kişilerin aynı soru hakkında farklı düşüncelerinin görüşülenlerden elde edildiği tarzda aktarılır. Betimsel ve sistematik analizde elde edilecek sonuçları daha sistematik belirlemek üzere; konuşma metinlerinin yazıya dökülmesi, alınan cevapların sınıflandırılması gibi yöntemlerin belirlenmesidir. Görüşmelerden elde edilen veriler kodlama sistemi ile sayısal verilere dönüştürülür ve analizi yapılır. Karmaşık bir yöntem olmasına rağmen ulaşılması oldukça zor veriler elde edilmiş olur. Betimsel analizde; elde edilen veriler, önceden belirlenen başlıklar altında özetlenir ve yorumlanır (Altunışık, 2010). Burada açıklandığı gibi, gözlemler ve görüşmelerden elde edilen tüm veriler en az iki lisans öğrencisinin kayıtlardan çözümleyerek kağıda aktarmasıyla ve karşılaştırılarak yorumlanmasıyla gerçekleştirilmiştir.

\section{BULGULAR}

\section{1. Öğretmenlerle Yapılan Görüşmelere İlişkin Bulgular}

Öğretmenlerle yapılan görüşmeler sonucunda öğretmenler, çocukların gelişimlerinin farklı öğrenme ortamlarında desteklendiğini, ilk kez üniversite ve kampüs ortamı görmeleri, üniversite hakkında bilgiler edinmeleri sonucunda farklı bakış açılarına sahip olduklarını düşündüklerini, çocukların ilk kez kutu oyuncakları ile oynadıklarını, sistemli bir kütüphane ortamına girdiklerini, bazılarının ise ilk kez otobüsle uzun süre seyahat ettiklerini, aynı zamanda kendilerinin materyal açısından sınırlı bir sınıftan farklı oyuncak ve zengin materyallerle buluştuklarını belirtmişlerdir. Çocukların gruplara ayrılarak, her grupla ayrı ayrı kişilerin ilgilenmesinin projeye olan ilgi, merak, dikkat ve isteğin arttırıldığını belirtmişlerdir. Öğretmenlerin, yeni kavram oyuncakları ile tanıştı̆̆ gözlemleme firsatı bulduklarını söylemişlerdir. Öğretmenler görüşlerini şu şekilde dile getirmişlerdir:

Ö1: "Kutu oyuncaklarıyla oynarken eğlendiler, materyallere dokunarak oynamaktan hoşlandilar. Otobüste ilk kez 20 dakika gibi klsa bir seyahate çıkan ögrenciler vardl, ilk kez büyük bir kütüphaneye gittiler."

Ö2: "Okulun semti, her çocuğun genel olarak 2-3 kardeşinin olması, aileler tarafindan sadece temel ihtiyaçların karşılanması ve kız çocuklarının daha geri planda tutulmasından, çocukların eksik olan özgüvenleri daha fazla artt. Burada kendilerini daha da iyi ifade edebilme konusunda yeni bir deneyim yaşadilar."

Ö3: "Çocukların gelişimlerini desteklemek için ve onların üniversite ve kampüs ortamına görmelerini istediğim için katılmaya karar verdim. Çocuklara çok yararlı oldu."

Ö4: "Üniversite ortamı görmek hoşlarına gitti. Üniversite ve kampüs gezmek onların yeni bilgiler edinmesini sağladı. Üniversitede okumak istediklerini söylediler."

Ö5: "Bir daha gelmek istediler çünkü ortam çok güzeldi. Çok eğlenceliydi. 4-5 ayrı kişi ilgilenip her masada ayrı ayrı etkinlikler yaptılar. Bu durum hoşlarına gitti. Tekrar katılmak istediler."

Ö6: "Sinıfımız oyuncak ve materyal açısından yetersiz olduğu için yeni ve farklı oyuncaklar görme firsatım oldu." demiştir.

\section{2. Çocuklarla Yapılan Görüşmelere İlişkin Bulgular}

Çocuklarla yapılan görüşmelerde çocuklar "Kuki" adlı kukla ile oyunu çok sevdiklerini, ilk defa böyle bir oyun oynadıklarını, üniversite kampüsünün bahçesindeki gölün içinde kaplumbağa ve balıkların çok güzel olduğunu, ilk defa üniversiteye geldiklerini, yoga yaparken hayvan taklitlerini komik bulduklarını, ilk defa erkek öğretmen ile karşılaştıklarını belirtmişlerdir. Çocuklardan birkaçı görüşünü şu şekilde dile getirmiştir:

Ç1: "Süt diyen oyuncağı sevdim, bana öpücük yaptr. Legolart sevdim. Kutu oyuncaklara dokunmak ve içinden ne çıkacă̆ını beklemek çok eğlenceli."

Ç2: "Çok büyük binalar vard,, bir sürü merdiven çıktım. Bahçede su vardl, suyun içinde kocaman kaplumbağa ve turuncu balıklar vardl. Kuki bana 'çak' yaptı. Bence beni çok sevdi, bende onu." 
Ç3: "Hayvanların taklidini yapınca çok güldüm. Öğretmenim erkekti ve bizimle oynadı. Bir daha gelmek istiyorum."

Ç4: "Merdiven çıkınca bir oda vardı. Bir sürü kitap vardı. Öğretmenimiz bize okudu. Hepimiz çok sessiz olduk, dinledik." demiştir.

\section{3. Öğretmen Adaylarıyla Yapılan Görüşmelere İlişsin Bulgular}

Öğretmen adayları ile yapılan görüşmelerde, öğretmen adaylarının bu uygulamaların, lisans eğitimlerinde gerçekleştirecek olan uygulamaları için katkı sağladığı, uygulamalara katılmadan önce kendilerini daha yetersiz hissettikleri ve uygulamalar sayesinde birçok deneyim elde ederek yeni bilgiler öğrendikleri belirlenmiştir. Öğretmen adayları görüşlerini şu şekilde dile getirmiştir:

ÖA1: "Bu uygulamaya katılırken üçüncü sinıf ögrrencisiydim. O zamanlar okul deneyimi dersine gidiyordum ve 36-48 ay grubu çocuklarla uygulamalar yapıyordum. Uygulamalarda kendimi yetersiz bulduğum alanlar vardı. Özellikle sını yönetimi konusunda çok güçlük çekiyordum. Etkinlik ve oyun üretmek çok zor geliyordu. Fakat her hafta bu proje kapsamında uygulamalara katıldım. Şu an dördüncü sinıftayım çocuklarla uygulama yaparken iletişimde, sınıf yönetiminde, bütünleştirilmiş etkinliklerin uygulanmasında, etkinlikler arası geçişleri sağlamada ve aktif pasif dengesini sağlamada kendimi daha yeterli, daha özgüvenli ve daha başarılı hissediyorum. Bu projede çok fazla oyun öğrendim. Her çocuk grubuyla çalışma firsatı bulduğum için yaş gruplarına göre nasıl davranacağımı daha iyi ögrendim. Aynı zamanda üniversitede teorik olarak gördügüm dersleri pratiğe çevirme firsatı buldum. Projede bazen iki sınıfa aynı anda etkinlik uyguluyorduk. Bu sayede kalabalık gruplarda yönetimi nasıl sağlayacağımı ve birçok çocuğu aynı anda etkinliklerde nasıl aktif kılabileceğimi öğrendim. Kavram oyuncaklarıyla çocuklara kavramların nasıl pratik ögretileceğini anladım. Proje benim ilerideki meslek hayatıma çok şey kattı. "

ÖA2: "Gönüllülük esaslı bir proje olduğu ve bu projeden yer alarak manevi bir sorumluluğu yerine getirme duygusu için bu projede görev almak istedim. Yaşadı̆̆ımız toplumda sorumluluklarımızı yerine getirirsek ülke olarak daha fazla gelişebileceğimize inandiğım için katıldım."

ÖA3: Öğretmen adayı "Gittiğim bütün stajları göz önünde bulundurarak uygulamalara gitmeden önce sınıf hakimiyetimin biraz zaylf olduğunu biliyorum. Proje kapsamında gittiğimiz uygulamalara bazı zamanlar tek kişi olarak gidiyorduk ve bu durumda çocuklara tek kişi olarak hitap etmeliydim. Uygulama sonunda gördüm ki bir gruba dahil olmadan da bir sinıfi yönlendirebiliyorum."

ÖA4: "Bir kere gittim. Gönüllülük esaslı bir proje olduğu ve bu projeden yer alarak manevi bir sorumluluğu yerine getirme duygusu için bu projede görev almak istedim. Yaşadığımız toplumda sorumluluklarımızı yerine getirirsek ülke olarak daha fazla gelişebileceğimize inandiğım için katıldım."

ÖA5: "Tam hatırlamıyorum ama 4-5 haftadan fazlaydı sanırım. Projede kısmi zamanlıda çalıştı̆̆ım için görev verildi buna bağhl olarak katıldım. Ulaşım konusunda zorlansam da genel anlamda iyiydi. Ilk uygulamamda çocuklarla birbirimizi tanımadı̆̆ımız için heyecana da bağlı aksaklıklar yaşadık ama bu zamanla alıştığımız için daha iyi geçti."

ÖA6: "Projede yer almak beni mutlu etmişti ve çocuklara karşı faydalı hissettirmişti. İlk uygulamada çocuklar ve ögretmen bizi sinıfa girer girmez benimsemişlerdi ve etkinlikleri hepsi heyecanla bekliyorlardl. Bu nedenle gerek çocuklarla gerek öğretmenle sağllklı ve güzel bir ilişki kurulmuştu. Uygulama bir kere gitmiş olmama rağmen bana bir ögretmen adayı olarak gerçekten farklı deneyim ve tecrübe kattl. Gittiğim okul, daha önceki ders kapsamında gittiğim okullardan gerek imkân gerekse mevcut bakımından çok farkllydı. Bu nedenle her şeyden önce farklı bir sinıf ortamını tecrübe etmeme olanak să̆ladı."

ÖA7: "Son sinıf ögrencisi olarak gittiğim bütün stajlarl göz önünde bulundurarak uygulamalara gitmeden önce sinıf hakimiyetimin biraz zaylf olduğunu biliyordum. Proje kapsamında gittiğimiz uygulamalarda bazı zamanlar tek kişi olarak gidiyorduk ve bu durumda zorunlu da olsa tek başıma çocuklar hitap edebilmeliydim. Uygulama sonunda gördüm ki bir gruba dahil olmadan da bir sinıfi yönlendirebiliyordum."

ÖA8: "İlk uygulamada heyecanliydım. Hem öğretmenlerle hem de ögrrencilerle iletişimim iyiydi. Farklı özelliklere sahip çocuklar tanıdım, okullarda eğitim veren ögretmenlerin çocuklarla iletişimlerini gözlemledim. Uygulamada çok fazla çocuk ile çalıştık, oyuncakların iki kişilik veya 4 kişilik olması bizim zorlanmamıza sebep oldu, bu oyuncakları diğer çocukların da sıkılmayacağl şekilde oynatmaya çalıştık. Bu da sinıf yönetiminde gelişmemizi ve alternatifler düşünmemizi sağladı."

ÖA9: "Bu uygulamaya gitmeden önce aslında derste gördügüm teorik bilgilerle kendime güvenim olduğunu düşünüyordum ama uygulamaya gittikten sonra kendime gereğinden fazla güvendiğimi gördüm çünkü teoride gördüğüm şeyleri pratiğe dökemediğimi fark ettim bunun için bayağı üzüldüm. Bu uygulamanın bana kattığı en büyük katkı kendime olan güvenimi arttırmasl ve şimdiden kazandırdığı tecrübeler oldu." 
ÖA10: "Bu uygulamaya gitmeden önce birçok yaş grubu ile etkinlikler gerçekleştirmiştim. Bu proje kapsamında çocukların gelişim özelliklerini genel hatları ile bilip ortak bir payda oluşturarak etkinlikleri yürütmek zorundaydım. Çocukların çok meraklı olması hemen oyun oynamak farklı şeyler ile karşılaşmak istemesi bu süreci oldukça ĕglenceli ve rahat kuldl."

ÖA11: "İkinci sınıf olduğum için ve daha önce çocuklarla pek bir arada bulunmadığım için biraz tedirgin oldum. Özellikle ögretmenleri başımızda yani sınıfta bulunduğu için tedirginliğim daha da arttı. Onlarla konuşurken biraz çekiniyordum acaba çocuklar oyunu beğenecekler mi veya ögretmenleri bizi eleştirecek mi bu açıdan tedirgindim. Tabi bu tedirginliğim iletişim kurmamı etkiliyordu. Daha sonraki uygulamalar daha iyi geçti en azından ne yapacağımı biliyordum. Çocuklara bir oyun ve bir şeyler öğretmek beni mutlu ediyor. O çocuklarla geçen her dakika kendime daha çok şeyler katmam gerektiğini ve ne kadar eksik olduğumu görüyorum."

ÖA12: "Illk başta ne yapacağım, nasıl vakit geçecek diye düşünüyordum ama sonra eksiklerimin olduğunu fark ettim vaktin nasıl daha verimli ve güzel kullanabilirim diye düşünmeye başladım. Şu an çocuklarla oynarken vaktin nasıl geçtiğinin bile farkında değilim ve eskisinden daha iyi sabırlı olmayı öğrendim."

ÖA13: "Okul kapsaminda gittiğimiz uygulama anaokullarında gördüğüm çocuklardan başka çocuklarla çalışmak yeni deneyimler elde etmeme sebep oldu. Projelere devamlılık gösteren çocukların gelişimlerindeki farkl gözlemleyebiliyorum."

ÖA14: "Farklı deneyimler yaşamak, çocukların mizaçlarını bilmek, öğrendiğim yeni şeyleri uygulamalı olarak gerçekleştirmek benim için çok faydalı oldu. Bilgilerimi deneyimlemek ise bana farklı bir özgüven verdi. Kendimi daha iyi hissettim. Daha mutlu oldum ve çocuklarla çok eğlendim. Yeni fikirler, oyunlar, etkinlikler ögrenmek ve bunları uygulayı ileriye dönük notlar, ipuçları almak benim için hem pratik hem de geliştirici oldu. En çok da çocuklara yararlı oldu. Bu projede yer almak beni memnun etti. Mutluyum." demiştir.

\subsection{Velilerle Yapılan Görüşmelere İliş̧in Bulgular}

Velilerle yapılan görüşmelerde, çocuklarının çok eğlenerek oynadıklarını, yeni bir ortama girilmesinin çocuk açısından farklılık oluşturduğunu, yeni şarkılar öğrendiklerini, hem çocukların hem de kendilerinin ilk defa bir erkek okul öncesi öğretmeni adayı ile karşılaştıklarını, çocukların sınıf arkadaşları dışında mahalle arkadaşlarına da öğrendiği oyunları öğrettiklerini, ilk defa çocuk yogası ile karşılaştıkları, evde de bazı zamanlarda çocuk yogası yapmaya başladıklarını belirtmişlerdir. Velilerden birkaçı görüşıerini şu şekilde dile getirmiştir:

V1: "Oyunların hepsi güzeldi fakat birkaçı daha etkiliydi. Kartlarla oyunlar kızımın en çok eğlendiği oyundu. Ama oyun dışında farklı bir ortama girmesi üniversite görmesi benim için en değerlisiydi. Kızım oyunlar oynanırken çok eğlendi. Sonrasında sohbet ettik ve mahalle arkadaşlarına da anlattı. Öğretmenler çocuklarla çok güzel iletişim kurdu. Arkadaşlarlyla çok uyumlu oynadı."

V2: "Oyunların hepsinden çok memnun kaldık. Eğitici oyunların olması çok güzeldi. Çocuğum çok utangaç ve kapanık olmasına rağmen yeni tanıştı̆̆ öğretmenleriyle çok iyi iletişim kurdu. Öğretmenlerinden biri erkekti ve çok şaşırdl. Sürekli o abi gibi olmak istiyorum diyor ve yeniden oraya gelmek istiyor."

V3: "Oyunlar güzeldi süreci beğendim, ögretmenlerin bütün çocuklarla ilgilenme çabası beni çok mutlu etti. Öğrendiği oyunları hala oynuyor. O gün yoga yapılmıştı ilk defa yoga yaptı bende ilk defa yoganın nasıl yapıldı̆̆ını gördüm. Evde arada müzik açarak öğrendiğiniz hareketlerle yoga yapıyoruz. Öğrendiği şarkıları evde söylüyor. İlk defa girdiği bir ortamda gayet girişkendi ve hemen uyum sağladl."

V4: "Oyunların hepsinden çok memnun kaldım. İlk defa gördügüm oyunlar vardı. Aynı zamanda ilk defa erkek öğretmen görmüşüm ve oldukça şaşırttı beni. Çocuklarla çok güzel oyunlar oynadı ve ilgilendi. Çocuğumun süreçte çok eğlendiğini gördüm. Tüm oyunlar içerisinde çok sevdiği bir oyun vardı, süt mü istersin çak mı istersin kafadan muz kayma mı istersin oyunuydu. Evde eline aldı̆̆ her şeyle bir kukla gibi sürekli bu oyunu oynuyor. Mutlaka tekrar gelmek istiyor." demiştir.

\section{5. Öğretmen Adaylarının Yaptıkları Gözlemlere İlişkin Bulgular}

Öğretmen adaylarının eğitimler sırasında tuttukları notlar ve yine eğitimler sirasında alınan video kayıtlarının çözümlenmesiyle yapılan gözlemlerde, öğretmen adaylarının çocukların bilişsel, dil, motor ve sosyal-duygusal gelişimleri ile özbakım becerilerinde olumlu yönde değişim gösterdikleri belirlenmiştir. Notlar ve gözlemlerin kaydedildiği videoların çözümlerinin değerlendirmesini gerçekleştiren öğretmen adaylarından birkaçı görüşlerini şu şekilde dile getirmiştir:

ÖA1: "İlk uygulamalardaki video kayıtlarından ve gözlemlenen diğer uygulamalardaki tutulan notlardan yola çıkarak projelere katılan çocukların kendini ifade etme becerilerinde, sosyal ilişkilerinde, çocuk şarkıları 
bilmekte, hareketli oyunlarda kurallara uymakta ve kavram bilgilerinde eksiklik olduğu gözlemlenmiştir. Çocuklarla oynanan tanışma oyunlarında çocukların isimlerini bile söylemekte çekindikleri gözlemlenmiştir. Bu gözlemlerden yola çıkllarak sonraki uygulamalarda etkinlik girişlerinde ısınma etkinlikleri, gevşeme egzersizleri ve eğlenceli tanışma oyunları oynanıp çocukların dikkatlerini çekmek ve süreçte daha aktif katılım göstermelerini sağlamak amaçlanmuştır.

Etkileşimli kitap okuma sırasında çocukların okunan kitaplardaki birçok kelimeyi tam olarak anlayamadıkları farkedilmiştir. Sonraki uygulamalarda çocuklara bilemedikleri kelimeler üzerinden anında dönütler verilmiş ve o kelimeler anolojiyle, somut nesnelerle ve günlük yaşamdan örneklerle açıklanmaya çalışılmıştır. Çocukların ilerleyen uygulamalarda öğrendikleri kelimeleri cümle içinde kullandı̆̆ görülmüsstür.

Çocukların üniversitedeki ilk uygulamalarda çekingen davrandiklarl ve onlarla konuşan bireylerle iletişim kurmadıkları, aynı zamanda kendi aralarında da iletişsimin kısıtlı olduğu gözlemlenmiştir. Bu gözlemlerden yola çıkılarak çocuklarla işbirlikli oyunlar oynanmış ve her çocuğun sürece aktif katılımı sağlanmaya çalışılmışıtır.

Çocukların kavram bilgilerindeki eksiklikler gözlemlendikten sonra kavram oyuncaklarıyla tanıştırılmış ve kavram oyuncakları küçük gruplarla oynanmış ve her çocuğa tekrar oynama firsatı tanınmıştır. İlerleyen uygulamalarda çocukların kavram oyuncaklarını tanıdığı ve hangi kutu oyuncağında hangi kavram olduğunu söyledikleri gözlemlenmiştir.

Çocukların ifade edici dil becerilerine katkı sağlamak amacıyla çocuklara çocuk şarkıları ögrretilmiş, ögretilen bu şarkılar sırasında Orff Schulwerk yaklaşımı temel alınarak bedeniyle ritim tutarak şarkllara eşlik etmeleri sağlanmıştır. Çocukların şarkılar sırasındaki hareketleri oyunlaştırılmış ve oyunlarda kurallar belirlenmiştir. Çocukların ilerleyen uygulamalarda kurallara daha fazla uymaya çalışarak oyunları oynadıkları ve bu süreçte de şarkıları hareketlerle bağdaştırarak ögrendikleri gözlemlenmisttir."

ÖA3: "Katılınan uygulamalar sırasında alınan anektod kayıtları, çekilen resimler ve video kayıtlarından yola çıkarak projedeki çocukların iletişim konusunda yetersiz olduğu gözlemlenmiştir. Bu yüzden ilk etkinlikler iletişim üzerine kurulmuştur. Tanışma oyunları, hareketli oyunlar ve sohbetler sayesinde ilerleyen uygulamalarda çocukların kendilerini daha iyi ifade ettiği gözlemlenmiştir.

Çocukların büyük bir kısmının ilk defa ilçesinden dışarı çıktığı veliler ve öğretmenler tarafindan ögrenildi. Bu yüzden çocuklarla sadece sinıfla değil drama salonu, bahçe, kütüphane ve üniversite gezilmiştir. Sonraki uygulamalarda çocukların çekingen davranışlarında azalmalar gözlenmiştir.

Çocuklarla kavram oyuncakları oynanmış ve çocukların çoğu kavram tanımada güçlük çektiği tespit edilmiştir. Bilinmeyen kavramlar üzerine yoğunlaşılmış ve sonraki uygulamalarda çocukların hem o kavramları hem de süreçte gizil olarak ögrendikleri diğer kavramları bildikleri gözlenmiştir."

ÖA8: "İlk uygulamalarda alınan notlar ve izlenen video kayıtları değerlendirildiğinde, çocukların daha çekingen oldukları gözlemlenmiştir. Daha sonraki kayıtlarda ise daha aktif katılmaya başladıkları belirlenmistir.

Başlarda, ögretmenlerine alışık oldukları ve yabancı yetişkinlerle etkinlik yapmaya istekli olmadıkları gözlenen çocuklar, sonraları öğretmen adaylarıyla da kaynaşarak neşeli biçimde oyunlar oynamışlardır. Çocukların genelinin Orff Schulwerk yaklaşımındaki oyunları ilk kez deneyimlemek sinıflarında da benzer uygulamalar yaptıklarını söylemişlerdir. Alınan anekdot kayıtları ve diğer kayıtlardan yola çıkılarak çocukların özellikle sosyal-duygusal ve dil gelişimlerinde ilerlemeler kaydettikleri gözlemlenmiştir."

ÖA12: "Yoga uygulamaları sırasında yapılan gözlemlerde, çocukların ilk uygulamalarda hareketleri gerçekleştirirken dengede durmakta, vücutların esnetebilmekte ve etkinliğe dikkatlerini uzun süre vermekte zorlandıkları sonucuna ulaşılmıştır. Ancak ilerleyen uygulamalarda, çocukların yoga uygulamalarına daha fazla ilgi gösterdiği, vücut esnekliklerinin daha fazla arttı̆̆ ve hareketleri daha kolay yapabildikleri gözlemlenmiştir.

Bahçe oyunlarında, çocukların aktif katılım gösterdikleri, geleneksel oyunları oynamayı sevdikleri ve çevrelerindeki yetişkinleri de zamanla oyuna davet ettiklerine dair notlar alınmıştır. Bahçe oyunları ve yoga uygulamalarının video kayıtları sonucunda çocukların psiko-motor, sosyal-duygusal ve dil gelişimi alanlarında ilerlemeler kaydettikleri gözlemlenmiştir.

ÖA13: "Uygulamalar sırasında alınan notlar ve çözümlenen videolardan hareketle uygulamalar gerçekleştirilmeden önce çocukların yaşıtlarına göre özellikle bilişsel ve dil gelişiminde geriden gelen bir gelişim gösterdikleri belirlenmiştir. Kavram oyuncaklarıyla ilk kez oyunlar oynandiğı sırada 5 yaşındaki çocuklardan birkaçı basit ikili örüntüyü örneğe bakarak yapabildiği halde kendileri ikili örüntü oluşturamamaktaydl. Eksikliği fark edilen bu yön ile ilgili olarak oyunlar gelişstirilmeye çalışılmış ve oynanmıştır. İlk uygulamalar sırasında çocukların örüntünün ne demek olduğunu bilmedikleri, örnek olarak 
hazırlanan örüntüyü bilinçsiz bir taklitle kopyaladıkları tespit edilmiştir. Bu nedenle çocuklara temel olarak örüntü kavramının ne olduğu ögretilmiş ve örüntü ile ilgili uygulamaların daha sonraki çalışmalarda da gerçekleştirilmesine özen gösterilmiştir. Öğretmenlerden de sinfflarında örüntü içerikli etkinliklere ağırlık vermesi istenmiştir. Gruptaki çocuklar ile gerçekleştirilen son uygulamada ise çocukların ikili örüntü oluşturabilmekle birlikte, oluşturulmuş üçlü örüntüyü devam ettirebildikleri ve kendileri üçlü örüntüler yapabildikleri gözlemlenmiştir.

Çocukların dil gelişiminde geride oldukları, kelime dağarcılarının akranlarına oranla daha dar olduğu ve bildikleri bazı kelimelerin telaffuzunu yanlış yaptıkları ya da bildikleri diğer kelimelerle karıştırdıkları ilk uygulamalarla anlaşılmıştır. Örneğin, merdivenlerden çıkarken çocuklardan biri trabzanlara tutunarak 'AA işte bir trabzon.' demiştir. Yanında bulunan ögretmen adayı çocuğa anında dönüt vererek 'Evet burada bir trabzan var.' demiştir. Çocuğun kavramları karıştırmaması için kavramların resimleri çocuğa gösterilmiş ve isimleri söylenmiştir. Bu yapılan çalışmalarla birlikte fakültemizin kütüphanesinde bulunan çocuk kitaplarından etkileşimli kitap okuma tekniği ile çocuklara kitap okunmuştur. Kitaplar okunurken çocuklara kitap içerisinde geçen bir kelimenin ne olabileceği sorulmuş ve çocuklara cevaplamakta çekinmemeleri için güdüleyici sözler söylenmiştir. Bu sayede çocukların üniversitedeki birkaç tekrardan sonra dil gelişimleri ile birlikte özgüvenleri ve kendini ifade etme becerilerinin de geliş̧mesine katkı sağlanmışıtır.

Çocuklar uygulamaların başında birçok şarkı bilmekteydi fakat şarkılarla birlikte uygulanan ritmik çalışmalarını daha önce yapmamış oldukları gözlemlenmiştir. Bu nedenle Orff Schullwerk yaklaşımını temel alan müzik etkinlikleri gerçekleştirilmiştir. Gerçekleştirilen uygulamalarda çocukların müziği dinleyerek birtakım hareketler yapmasını gerektirecek, beden perküsyonu ve zaman, mekan algısını geliştirecek etkinliklere yer verilmiştir. Bu etkinlikler bütünleştirilmiş müzik ve hareket etkinlikleri kapsamında olup çocukların motor gelişimlerine de katkı sağlamıştır. Ritmik çalışmalar şarkılar ile gerçekleştirilmeden önce ritmik heceleme çalışmaları ile çocukların ritim duygularının geliştirilmesi amaçlanmıştır. Tekrarlayan uygulamalar sonunda ise çocukların şarkıya uygun ritim tutabildikleri ve ritim tutarken sadece ellerini değil tüm bedenlerini kullandıkları gözlemlenmiştir. Bununla birlikte çocukların kendi aralarında oyun oynarken uygulamalarda kullanılmamış olan kelimelere yönelik bedenlerinin farklı bölümlerini kullanarak ritmik heceleme oyunları oynadıkları da gözlemlenmiştir.

Gerçekleştirilen uygulamaların tümünde özbakım becerilerinin gelişmesini destekleyecek ortamlar çocuklara sunulmuştur. Örneğin çocuğun annesi sinıfta ise ve çocuk, burnu aktığında annesinden silmesini istiyor ya da burnunun aktı̆̆ını fark etmiyor ise anneden, çocuğun bunu öğrenmesi için burnunun aktığını söylediğinde ona sadece peçete vermesi ve çocuğun kendi burnunu silmesinin beklenmesi veya çocuk burnunun aktığını fark etmiyor ise belli bir süre tanıyarak onun fark edip de burnunun aktı̆̆ını söylemesi istenmiştir. Benzer uygulamalar çocukların tuvalet ihtiyaçlarını kendi kendilerine giderebilmeleri konusunda da yapılmış, gönüllü katılan veliden, ögretmenden, yardımcı ögretmenden veya ögretmen adayından yardım istemeden tuvalet ihtiyacını karşılayan çocuklar sözle ödüllendirilmiştir.

Yapılan gözlemlerden edindiğim bilgilere göre çocukların uygulamalar gerçekleştirilmeden önceki gelişim düzeyleri ile karşılaş̧ırıldiğında tekrarlayan uygulamalar sonrasında gelişimlerinde olumlu yönde değişim gösterdiğini söyleyebilirim."

ÖA14: "Uygulamalar sirasında kaydedilen videolar ve yapılan gözlemlere ilişkin alınan notlardan yola çıkarak çocukların sosyal-duygusal gelişim alanında önemli gelişmeler kaydedildiği sonucuna ulaşıldı. Örneğin, çocukların katıldıkları ilk uygulamada, iletişim becerileri zayıftı. Tanışacak olduğu kişilere "merhaba" bile demek istemiyor ve o kişiden uzak duruyorlard. Bu durum da, çocukların ilk uygulamada aktif olmalarını engelliyordu. Drama çalışmalarımız içerisinde yer alan "buz kırma" teknikleri kullanıldı̆̆ında, çocuklar daha aktif hale geldi. Uygulamalara iki ve daha fazla katılan çocukların ilk kez karşılaşmış oldukları ögretmen adaylarına ismini sordukları ve onlarla sohbet başlatabildikleri gözlemlenmiştir.

Çocuklarla kütüphanede gerçekleştirilen ilk etkileşimli kitap okuma çalışmasında çocuklar, bir kitabın yazarının olduğunu, yayınevi tarafindan yayımlandı $\breve{l}$ gibi bilgileri bilmiyor iken projenin son uygulamalarına doğru kitabı okumaya başlamadan önce kitabın yazarının kim olduğunu kendileri sorabilecek düzeye geldikleri gözlemlenmiştir." demiştir.

\section{TARTIŞMA, SONUÇ VE ÖNERILER}

\section{Tartışma ve Sonuç}

Araştırma kapsamında, okul öncesi dönemde bulunan çocukların beden, zihin, dil ve duygu gelişimini çeşitli oyun, kavram oyuncakları, çocuk yogası, açık hava oyunları, yaratıcı drama etkinlikleri ve Orff Schulwerk temelli müzik etkinlikleriyle desteklenmiştir. Şartları elverişsiz aile ortamından gelen bu çocukların 
ihtiyaçları doğrultusunda toplumdaki diğer çocuklar arasında firsat eşitliği sağlanmaya çalışılmıştır. Çocukların zihinlerinde "üniversite", "meslek" gibi kavramların şekillenmesine destek verilmiş, fakültede yer alan Çocuk Kütüphanesi'ni deneyimleyerek ve kampüsteki doğal bitki örtüsünü tanıyarak açık alanlarda çeşitli etkinliklere dahil olmuşlardır. Okul öncesi öğretmenlerinde, farklı tür etkinlikleri uygulama ile kavram oyuncakları gibi değişik materyalleri kullanma yönünde farkındalık oluşturmaya çalışılmış, öğretmenlerin mezun olduktan sonra yeniden fakülteye gelerek öğretim ortamlarını solumaları ve kendilerini geliştirme yönünde çaba göstermeleri teşvik edilmiştir. Yarı yapılandırılmış görüşme formlarındaki ve gözlem formlarındaki kayıtlarından edinilen bilgilere göre, çocuklar üniversitede gerçekleştirilen bu etkinliklere birden fazla katılım gösterdiklerinde tüm gelişim alanlarında olumlu ilerlemeler görüldüğü, çocukların grup iletişimini destekleyecek kavram oyuncaklarıyla ilk kez karşılaşıtıları, severek ve eğlenerek öğrendikleri ve birbirleriyle etkileşime girerek oyunlardan yararlandıkları, Orff Schulwerk yaklaşımı, çocuk yogası ve yaratıc1 dramadan vb. yararlanılarak oynanan oyunların geliştirici olduğu sonucuna ulaşılmıştır. Çocuk yogası etkinliklerinin daha çok psiko-motor gelişim alanında; bahçe oyunları ve Orff Schulwerk yaklaşımı temelli etkinliklerin özellikle sosyal-duygusal, dil ve psiko-motor gelişim alanlarında; etkileşimli kitap okuma ve kavram oyuncakları etkinliklerinin ise daha çok bilişsel ve dil gelişimi alanlarında çocuklara katkı sağladığı belirlenmiştir. Çelik'in (2005) yürüttüğü çalışmada da, benzer biçimde, okul öncesi dönem çocuklarının çeşitli teknik ve oyuncaklardan faydalanılarak en zor kavramları dahi öğrenebildikleri sonucuna ulaşmıştır. Bu oyuncakların geliştirilmesinde özellikle üniversitelerden yararlanma yoluna gidilmesi gerektiği belirtilmiştir.

Öğretmen adaylarının, farklı çocuk gruplarıyla oyun ve oyuncaklarla oynamaları yoluyla deneyimlerini arttırmaları hedeflenirken, lisans öğrenimlerinde edindikleri teorik bilgileri projeye dahil olan çocuklarla deneyimleme firsatı bulmuşlar, her yaş grubundan yeni ve dersleri kapsamında gittikleri uygulamalardan farklı sosyo-ekonomik düzeylerden gelen çocuklarla uygulama yapma olanağına sahip olmuşlardır. Aynı zamanda öğretmen adayları, aldıkları anekdot kayıtları ve video çözümlemeleri sayesinde çocukları değerlendirme, gelişim izleme ve süreç yönetimi konusunda daha fazla tecrübe kazanmışlardır. Paralel biçimde, gerçekleştirmiş olan bir başka araştırmada da lisans öğrencilerinin sosyal sorumluluk projeleri sayesinde sosyal açıdan sorumlu bireyler olmasının yanında akademik olarak da gelişme gösterdikleri belirlenmiştir (Taş, 2017).

Projelere gönüllü olarak katılan velilerin ise uygulamaları izleyip çocuklarının gelişimlerini gözlemleyerek okul öncesi eğitimin önemini kavramaları, çocuklarına nasıl destek olabileceklerini belirlemeleri sağlanarak projenin nihai amaçlarına ulaşılmaya çalışılmıştır. Webster-Stratton, Reid ve Hammond (2001)'ın Head Start programında veli ve öğretmen eğitimiyle ilgili araştırmalarında deney ve kontrol grubu oluşturmuş, deney grubuna 12 seanslık program uygulamış ve seanslar sonucunda deney grubunda en yüksek risk altındaki çocukların, bu araştırmaya paralel biçimde, gelişimlerinde olumlu yönde anlamlı değişim sağlandığı sonucuna ulaşılmıştır.

Konuyla ilgili olarak projeye katılan öğretmenlerde, olumlu yönde görüş değişiklikleri yaşanmıştır. Bazı öğretmenler, projedeki uygulamalar sırasında kullanılan oyuncak, hareketli oyun, şarkı ve tekerlemelerin çocukların çok yönlü gelişimini sağlama konusunda yararlı olduğunu ve çocukların daha istekli biçimde etkinliklere katıldıklarını gözlemlediklerini ifade etmişlerdir. Eğitimin her çocuğun hakkı olduğu, öğretmenlerin çocuklar arasında firsat eşitliği sağlaması gerektiği anlayışıyla, çocuklarla sevgi ve güven bağı kurarak teorik bilgilerden elde edilen birikimle, yaparak yaşayarak öğrenme felsefesini güderek eğlenceli, öğretici oyun ve materyalleri kullanarak, kukla, yaratıcı drama, sanat, hareket, dans, çocuk yogası, Orff Schulwerk yaklaşımıyla müzik gibi etkinlikler yoluyla farklı yöntemlerle güçlü bir eğitim anlayışının farkındalığını sağlamak, tüm çocuklara ulaşabilmek, her çocuğun ihtiyacını karşılama konusunda çaba göstererek örnek teşkil ederek projenin amacına ulaşılmıştır. Bu araştırmaya paralel biçimde, 61-72 aylık çocukların sınıflarında zengin öğrenme materyallerinin kullanımı söz konusu olduğunda, çocukların özellikle dil, okuma yazmaya hazırlık ve matematik alanlardaki gelişimlerinin desteklendiği (Uyanık Aktulun ve İnal Kızıltepe, 2018); çocukların zengin içerikli ortamlara ve grup oyunlarına yöneldiği bulunmuştur (Uyanık Aktulun, Can Yaşar, Karaca, Akyol, Şenol ve Kaya, 2018). Benzer şekilde, Özdemir, Sefer ve Türkdoğan (2008)'ın yürüttükleri araştırmada dezavantajlı grup olarak değerlendirilen yuva çocuklarına yönelik "Korunmaya Muhtaç Çocuklar" isimli sosyal sorumluluk projesi gerçekleştirilmiştir. Gerçekleştirilen projelerde çocukların gelişimlerinin yanında projede gönüllü olarak çocuklarla ilgilenmekle görevli olan lisans öğrencilerine bir kolejin öğretmenleri tarafından eğitim verilmiştir. Bu sayede gönüllülerin farklı uygulama ve yöntemleri öğrenerek çocuklar ile birlikte eğitimler gerçekleştirdiği ve başarılı sonuçlar elde edildiği belirlenmiştir (Özdemir, Sefer ve Türkdoğan, 2008).

Veliler ile yapılan görüşmeler sonucunda çocukların süreç içerisinde eğlenerek öğrendikleri, birçok alanda özellikle çocukların kendini ifade etme becerilerinde gelişim gösterdikleri ve velilerin proje kapsamında 
deneyimleyerek öğrendikleri oyunları evde çocuklarıyla birlikte oynayarak çocuklarının gelişimlerine katkı sağladıkları sonucuna ulaşılmıştır. Dinçer, Ergül, Şen ve Çabuk (2011)'un yaptıkları araştırmada da, bu araştırma ile benzer şekilde, çocuklarını çalışmaya gönüllü olarak dâhil eden ailelerin, okul öncesi eğitimin gerekliliği konusunda elde ettikleri deneyimler doğrultusunda farkındalık geliştirdikleri ve projenin, çocukların kavram gelişimlerine önemli katkılar getirdiği ve sosyalleşme yönünde ilerleme kaydettikleri belirlenmiştir (Dinçer, Ergül, Şen ve Çabuk, 2011).

\section{Öneriler}

Araştırmanın sonuçlarının ışığında aşağıdaki öneriler verilebilir:

a. Okul Öncesi Öğretmenliği lisans programlarında topluma hizmet ve sosyal sorumluluk projeleri konusunda daha fazla uygulamalı dersler verilebilir ve verilen derslerin sayıları artırılabilir. Uygulamalı derslerden önce lisans öğrencilerine bulundukları şehirdeki alt sosyo-ekonomik düzeyde yer alan okullarda gözlem yapmaları için firsatlar tanınabilir. Diğer eğitim fakültelerinde de benzer projelerin gerçekleştirilerek sosyo-ekonomik düzeyleri düşük olan bölgelerdeki çocuklarla çalışmalar yapmaları önerilir.

b. Lisans öğrencilerinin benzer projelere katılıp farklı yaklaşımları ve etkinlik türlerini temel alarak çeşitli çalışmalar gerçekleştirmeleri önerilir.

c. Okul öncesi öğretmenlerine, yardımcı öğretmenlere ve grup sorumlularına sosyal sorumluluk projeleri ile ilgili eğitimler verilebilir. Araştırmaya katılan öğretmenlerin projeler aracıllğıyla gözlemlediklerini, katılmayan öğretmenlere ve idarecilere aktarmaları ve onları da benzer projeler yürütme konusunda teşvik etmeleri önerilir.

d. Araştırmaya katılan velilerin, projelerde öğrendikleri oyunları evlerinde çocuklarıyla daha çok uygulamaları ve katılmayan velilere bu oyunları anlatmaları önerilir. Okul öncesi çağda çocuğu olan aileler için eğitim kurumlarında, halk eğitim merkezlerinde veya eğitim fakültelerinde farkındalığı arttırmak için okul öncesi eğitimle ilgili seminerler, konferanslar vb. düzenlenebilir.

e. Okul öncesi eğitim kurumlarının yöneticilerine benzer projeleri okullarında uygulamaları için öğretmenleri teşvik etmeleri önerilir.

f. Araştırmacılar, tüm sosyo-ekonomik düzeylerde yer alan tüm kurum türlerine göre sosyal sorumluluk projelerini içeren daha çok nitel ve nicel araştırmalar geliştirebilir. Araştırmanın sadece Ankara ili ile sınırlı kalmaması, yayılması için Türkiye'nin yedi coğrafi bölgesinden seçilen okullarda benzer projelerin uygulanarak öğretmenler, veliler ve çocuklara yönelik görüşmelerin ve gözlemlerin gerçekleştirilmesi önerilir. Sosyal sorumluluk projeleri aracılığıyla çocuklar daha çok gözlemlenerek projelerin çocukların gelişimlerine sağladığı katkılar üzerine farkındalık oluşturulabilir.

\section{Teșekkür}

Araştırma kapsamında geliştirilen iki projenin hazırlık aşamasında verdiği destek ve proje etkinliklerinin gerçekleştirilebilmesinde sağladığı materyal yardımından dolayı Prof. Dr. F. Çağlayan DİNÇER'e; sürecin sağlıklı bir şekilde yürütülmesinde özverili çalışmalarından dolayı Ankara İli Mamak İlçesi Milli Eğitim Müdürlügü’nün AR-GE Birimi'nde görevli Uzman Güler TANRIVERDİ, Nurcan GÜNGÖREN ve Şeyma TOPÇU'ya; katılımlarından dolayı aynı ilçedeki okullarda görevli öğretmenlere, öğrencilerine ve velilerine; raporlaştırma sürecinde yardımlarından dolayı Öğretmen Buse OK ve Veysi TOKTAŞ'a; etkinlikleri uygulayan kısmi zamanlı ve gönüllü olarak çalışan öğrencilere teşekkür ederiz. 


\section{KAYNAKÇA}

Altunışık, R. (2010). “Sosyal Bilimlerde Araştırma Yöntemleri”. Sakarya: Sakarya Kitabevi.

Anderson, J. (1998). Service Learning and Teacher Education. ERIC Clearinghouse on Teaching and Teacher Education. Document Number: ED421481. Washington DC.

Ankara Üniversitesi Eğitim Bilimleri Fakültesi. (2006). Eğitim Bilimleri Bakış Açısıyla Eğitim Fakülteleri ve Topluma Hizmet İşlevi. Ankara: Ankara Üniversitesi Eğitim Bilimleri Fakültesi Yayınları.

Arı, M. ve Gönen, M. (1988). Dil Gelişimi ve Çocuk Kitapları. Ankara: Aşama Matbaası.

Başaran, N. (2006). "Erken Öğrenme Becerilerini Değerlendirme Aracının Tokat Örnekleminde 48-66 Aylık Türk Çocuklarına Uyarlanması”. Yayımlanmamış Yüksek Lisans Tezi, Gazi Üniversitesi Sosyal Bilimler Enstitüsü, Ankara.

Bailey, K. D. (1982). Methods of Social Research. New York: Free Press.

Bradley, R. H. \& Corwyn, R. F. (2002). "Socioeconomic Status and Child Development”. Annual Review of Psychology, 53, 371-399.

Büyüköztürk, Ş., Kılıç Çakmak, E., Akgün, Ö., Karadeniz, Ş. ve Demirel, F. (2017). Bilimsel Araştırma Yöntemleri. Ankara: Pegem Akademi.

Camgöz, A. (2010). “Ankara Örnekleminde Penn Etkileşimli Akran Oyunu Ölçeğinin 60-72 Aylık Düşük Sosyoekonomik Düzeydeki Çocukların Ebeveyn ve Öğretmenlerine Uyarlanması”. Yayımlanmamış Doktora Tezi. Gazi Üniversitesi Eğitim Bilimleri Enstitüsü, Ankara.

Carroll, A. B. (2001). The Moral Leader: Essential for Successful Corporate Citizenship. Perspectives on Corporate Citizenship. Sheffield, UK: Greenleaf Publishing.

Cevher, N. (2015). “Ankara'daki Halk Kütüphanesi Çocuk Bölümlerinin Çocukların Okuma Alışkanlığındaki Rolü”. Yayımlanmamış Doktora Tezi. Hacettepe Üniversitesi, Sosyal Bilimler Enstitüsü, Ankara.

Çelik, C. (2005). "Oyun Materyallerinin Okul Öncesi Eğitim Çağındaki Çocukların Kavram Gelişimi Üzerindeki Etkisinin İncelenmesi”. Yayımlanmamış Yüksek Lisans Tezi, Selçuk Üniversitesi, Sosyal Bilimler Enstitüsü, Konya.

Deniz Z., Türe E., Uysal A. ve Akar T. (2015). "Sosyo-ekonomik Düzey Değişkenlerinin Kümeleme Analizi ile Belirlenmesi”. İlköğretim Online Dergisi. 14(1), 108-117.

Dinçer, F., Ergül, A., Şen, M. ve Çabuk, B. (2011). "Bir Topluma Hizmet Uygulaması Örneği: Haydi Kavram Oyuncaklarıyla Oynayalım”. Kastamonu Eğitim Dergisi, 59(1), 19-38.

Duman, A. (2014). "Okulların Sosyal Sorumluluk Projelerini Yerine Getirebilme Yeterliliği”. Yayımlanmamış Yüksek Lisans Tezi, Yeditepe Üniversitesi, Sosyal Bilimleri Enstitüsü, İstanbul.

Garces, E., Thomas, D. ve Currie, J. (2002). “Longer-Term Effects of Head Start”. American Economic Review, 92(4), 999-1012.

Haktanır, G., Akgün, E., Karaman, G. ve Duman, G. (2012). “Topluma Hizmet Uygulamaları Dersi ve MEB Mobil Anaokulu Projesi’nin Birlikte Yürütülmesi ile Çocukların Gelişimlerinin Desteklenmesi: Peçenek Köyü Örneği’”. Kastamonu Eğitim Dergisi, 21(1), 69-82.

Kağıtçıbaşı, Ç. (1981). Çocuğun Değeri-Türkiye'de Değerler ve Doğurganlık. İstanbul: Gözlem Matbaacılık.

Kandır, A. ve Tümer B. (2013). "Farklı Sosyo-Ekonomik Düzeydeki Beş-Altı Yaş Çocukların Erken Öğrenme Becerilerinin İncelenmes”. Sosyal Politika Çalışmaları Dergisi, 13(7), 1-13.

Karasar, N. (2005). Bilimsel Araştırma Yöntemi. Ankara: Nobel Yayın Dağıtım.

Kuşçu, Ö. (2010). "Orff-Schulwerk Yaklaşımı ile Yapılan Müzik Etkinliklerinin Okulöncesi Dönemdeki Çocuklarının Dikkat Becerilerine Etkisi”. Yayımlanmamış Yüksek Lisans Tezi, Selçuk Üniversitesi Sosyal Bilimleri Enstitüsü, Konya.

MEB (2013). Okul Öncesi Eğitim Programı, Ankara: Milli Eğitim Bakanlığı Yayınları.

MEB (2018). 2023 Eğitim Vizyonu. Ankara: Milli Eğitim Bakanlığı Yayınları.

Merriam, S. B. (2013). Nitel Araştırma Desen ve Uygulama için Bir Rehber. S. Turan (Çev.). Ankara: Anı Yayıncılık.

Özdemir, N., Sefer, N. ve Türkdoğan N. (2008). "Bir Sosyal Sorumluluk Projesi Örneği: Korunmaya Muhtaç Çocuklar Örneği”. Cumhuriyet Üniversitesi Sosyal Bilimler Dergisi, 32(2), 283-305.

Patton, Q. M. (1987). How to Use Qualitative Methods in Evaluation. London: Sage Publications.

Taner, M. ve Başal, H. (2002). "Farklı Sosyoekonomik Düzeylerde Okulöncesi Eğitimi Alan ve Almayan İlköğretim Birinci Sınıf Öğrencilerinin Dil Gelişimlerinin Cinsiyete Göre Karşılaştırılması”. Uludağ Üniversitesi Eğitim Fakültesi Dergisi, 18(2), 395-420.

Taş, H. (2017). "Sosyal Sorumluluk Projelerinde Yer Almanın Üniversite Öğrencileri Üzerindeki Etkilerine İlişkin Öğrenci Görüşleri”. Yayımlanmamış Yüksek Lisans Tezi, Sakarya Üniversitesi Eğitim Bilimleri Enstitüsü, Sakarya.

Temel, Z. T. (2017). Erken Çocukluk Eğitiminde Yaklaşımlar ve Programlar. Ankara: Vize Yayıncılık.

TÜİK. (2017). Eğitim İstatistikleri. www.tuik.gov.tr.

Uyanık Aktulun, Ö., Can Yaşar M., Karaca N. H., Akyol, T., Şenol F. B., Kaya Ü. Ü. (2018). “Oyun Hakk1 Daha Fazla Oyun Projesi”. Türkiye Sosyal Araştırmalar Dergisi, 22(3), 17-33.

Uyanık Aktulun Ö. ve İnal Kızıltepe, G. (2018). "Using Learning Centers to Improve the Language and Academic Skills of Preschool Children". World Journal of Education, 8(6), 32-44. 
Webster-Stratton, C., Reid, M. J. \& Hammond, M. (2001). "Preventing Conduct Problems, Promoting Social Competence: A Parent and Teacher Training Partnership in Head Start”. Journal of Clinical Child Psychology, 30(3), 283-302.

Yıldırım, A. ve Şimşek, H. (2004). Sosyal Bilimlerde Nitel Araştırma Yöntemleri. Ankara: Seçkin Yayınları. 